\title{
ICDS and Its Impact on Child Health: A Study with Special Reference to West Bengal
}

\author{
Kingsuk Maity $^{1 *}$, Pinaki Das ${ }^{2}$ and Satya Narayan Kumbhakar ${ }^{3}$ \\ ${ }^{1}$ Assistant Professor of Economics, Shibpur Dinobundhoo Institution (College), West Bengal, India \\ ${ }^{2}$ Associate Professor, ${ }^{3} \mathrm{PG}$ Student, \\ ${ }^{2 \& 3}$ Department of Economics and Rural Development, Vidyasagar University, West Bengal, India \\ *Corresponding Author \\ E-Mail: kingsuk1974@yahoo.co.in, pdasvu@mail.vidyasagar.ac.in
}

\begin{abstract}
As we are well aware of the fact that India takes the praise of subsiding the largest child population in the world but at the same time, we cannot deny the bitter truth that it too has the highest rate of malnourished people and undernourished children in the world. Thus, the Indian government has taken numerous steps towards mitigating these miseries and ICDS is a vital step towards it. Through this paper, an attempt has been made to analyze the performance of ICDS and its impact on the status of child health across the districts of West Bengal using NFHS-III and NFHS-IV data. The study revealed that Children's nutritional status in West Bengal has significantly improved from 2005-06 to 2015-16. It is concluded the percentage share of underweight, stunted and wasting children have decreased in districts with higher women literacy rate and the concentration of AWCs.
\end{abstract}

Keywords: Integrated Child Development, Health Education, Woman Literacy, Child Health

\section{INTRODUCTION}

Today Integrated Child Development Services popularly abbreviated as 'ICDS' Scheme in India, represents one of the world's largest and most unique programmes for early childhood (aged 6 months to 6 years) development. In recent years, ICDS has a crucial role in pre-school education in one side whereas on the other it is an integrated package of minimum basic services such as care, nourishment and educational nurturance to children, adolescent girls and pregnant \& lactating mothers so as to reach a multitude of objectives encompassing children's improved health and nutrition status, development of their psychological competencies, preparation of adolescent girls for safe motherhood, mother's improved health and child bearing \& rearing practices. India continues to have high rate of malnourished people and undernourished children in the world. India is a home to the world's largest child (0-6 years) population of 158.8 million of which only 41.2 million resides in urban areas (Census 2011). The child population in urban areas increased by almost 3.9 million (10.32per cent) as compared to 2001 Census. Almost 43 per cent of children under five years of age in India are underweight and 48 per cent are reported as stunted in 2005-06 (NFHS-3). The rural population has a high prevalence of infant mortality rate (IMR) i.e. 46 per cent as well as 38.3 percent rural children are underweight. In
India, under five mortality rates has declined from 200506 to $2015-16$ but it is still as high as 50 per thousand children (NFHS-4). In 2015-16, U5MR was 56 per thousand children in rural areas whereas 34 per thousand children in urban areas respectively. Still 39 percent children were malnourished in 2015-16 (NFHS-4). Since a large portion of our country is constituted by children thus, nutritional status of children has become an important indicator to check the development status of the country. In West Bengal, IMR was 28 per thousand children and U5MR was 32 per thousand children in 2015-16(NFHS-4). Rural West Bengal has a high prevalence of these two than the Urban West Bengal. In the ICDS programmes there are various type of service that has been taken for each target groups. The beneficiaries from this programme can be classified into four categories namely, i) Children less than 3 years, ii) Children between 3-6 years, iii) Expectant and nursing mother and iv) Other women $15-45$ years. The provisional benefits for the children less than 3-6 years are Supplementary nutrition, Growth monitoring, Immunization, Health check-up and pre-school education. The mothers are benefited by regular Health check-up programme, various type of vaccination, nutrition \& health education and some home-based skill training programmes as they have a key role in the physical, psychological and social development of the child.

\section{A. Review of Existing Literature}

Chowdhury \& Mali (2016) analyzed the progress and bottlenecks of ICDS programme in West Bengal. Sayantani Mukherjee \& Pinky Rome (2015) was working on vulnerable sections of the society and suggested for more investment on children, especially of the vulnerable sections of the society. Rajesh K Chudasama et al., (2014) assessed the ICDS program in terms of infrastructure of Anganwadi Centers, inputs, process, coverage and utilization of services and the beneficiaries related to the program in operation in twelve districts of Gujarat, and informed about the poor coverage of this programme in those districts. Aadil Bashir et al., (2014) focused on the implementation of this scheme in Bandipora district in Jammu and Kashmir regarding package of services and reported that there is a growth of services under Anganwadi Centers. Tomohiro et al., (2007) 
concluded that there is a need for strong governmental maintenance over the process of ICDS. Sandhya Rani Mohanty (2017) reported that anemia was more prevalent among children in the non-ICDS areas. B.N. Tandon (1989) investigated the impact of the nutritional status of the target population of ICDS beneficiaries compared to nonICDS beneficiaries. They found that between 1976 and 1985, the drop in severe malnutrition for children covered by ICDS was substantial and statistically significant.

\section{B. Motivation of the Study}

From the brief review of the existing literature it is revealed that so many works have been done on ICDS program. Most of the researcher has examined the performance of ICDS across states in India or some regions in India. But the performance of ICDS on Child Health in West Bengal has not been adequately analyzed. Recently, West Bengal has witnessed an improvement in the number of health indicators. Therefore, the present study attempts to analyze the performance of ICDS across the districts of West Bengal and also to analyze its impact on the status of child health using NFHS $3^{\text {rd }}$ and $4^{\text {th }}$ round data (2005-06 and 2015-16).

\section{Objectives of the Study}

1. To explore the health facilities that was obtained by the children from ICDS

2. To analyze the impact of ICDS health facility on the status of child health.

\section{Hypotheses}

1. Health status of the children in the developed districts is significantly better than those in the backward districts.

2. The variation in the status of child health across districts is significantly explained by the performance of ICDS.

\section{DATABASE AND METHODOLOGY}

A. Database: While the overall objective of the present study is to estimate and analyze the ICDS programme and its impact on child health. We have tried to develop a comparative analysis at district level in West Bengal as well as analyzed their performance over time. For this purpose, we have taken resort to the secondary data. Secondary data have been collected mainly from three sources, namely National Family and Health Surveys (NFHS 3 and NFHS 4), Health on March 2015-16 and Indiastat.com.

\section{B. Methodology}

1. Equality Test: The equality of mean is tested by Fisher t-test (F-test) whereas the equality of variance is tested by F-statistics (t-test)

2. Dimension Index: This index is extensively used in the human development studies. Dimension Index (DI) is calculated for each sub indicator of the corresponding dimensions and then arithmetic mean of all DI of the corresponding indicator are taken as GDI. To calculate the Dimensional Index, minimum and maximum values have been taken from each indicator considering all states of India. Performance in each dimension is expressed as a value between 0 and 1 by applying the general formula:

Dimensional Index (DI), of each indicator is calculated by -

$$
\begin{aligned}
& \mathrm{DI}=\frac{\text { Actual value }- \text { Minimum Value }}{\text { Maximum value }- \text { Minimum Value }} \\
& \text { Group Dimensional Index }(\mathrm{GDI})=\sum \frac{\text { Sum of DIs }}{\text { No of sub indicator }}
\end{aligned}
$$

C. Ordinary Least Square (OLS): Ordinary least square (OLS) method has been used in the present study. The parameters are estimated by OLS in the classical linear regression model (CLRM). The model is specified by the regression equation as follows

$$
Y_{i}=\beta_{1}+\beta_{2} X_{2 i}+\beta_{3} X_{3 i} \ldots \ldots \ldots+\beta_{2} X_{2 i}+U_{i}
$$

Where, $\mathrm{Y}$ is the dependent variable, $\mathrm{X}_{\mathrm{i}}$ are the explanatory (regresses) variables, $\mathrm{U}$ is the stochastic disturbance term, and $\mathrm{i}$ is $\mathrm{i}$-th observation. The estimation by OLS method in CLRM is based on certain assumption.

\section{FINDINGS OF THE STUDY}

\section{A. Status of Beneficiary and Number of ICDS Centre across Districts of West Bengal}

The available evidence of the number of Anganwari Centers (AWCs) in the districts of West Bengal is presented in Table I. The following features are noteworthy as they help to explain the performance of ICDS in West Bengal. Firstly, in 2015-16 the number of AWCs varied from 1516 in Kolkata to 10640 in South 24 Pargana which implies that the AWCs was highest in South 24 Pargana followed by North 24 Pargana, Burdwan, Paschim Medinipur and Murshidabad whereas in 2005-06 the number of AWCs varied from 1020 in Darjeeling to 5015 in South 24 Pargana. During the period 2005-06 to 2015-16 the number of AWCs substantially increased in West Bengal as a whole.

Secondly, in 2015-16, per centre beneficiary of child and mothers varied form 24 per centre in Darjeeling to 101 per centre in Uttar Dinajpur i.e. the per center beneficiary were highest in Dinajpur followed by Murshidabad, Malda, South 24 Pargana, Medinipur and Purba Medinipur.

Thirdly, the percentage share of child benefited is an important variable to study the performance of ICDS. In West Bengal, 58.6 percent children were benefited from ICDS in 2015-16. The share of the child benefited in 201516 was highest in Jalpaiguri (93.1 percent) districts followed by Paschim Medinipur (92.1percent), Malda (90.9 percent), Birbhum (90.3percent), and Bankura (89 percent). The share of children benefited from ANCs in Hooghly district was less than 50 percent in 2015-16. 
Table I Status Of Beneficiary And The Number Of ICDS Centre ACross Districts Of West Bengal In 2015-16

\begin{tabular}{|c|c|c|c|c|c|c|c|}
\hline Districts & $\begin{array}{l}\text { No. of } \\
\text { AWCS }\end{array}$ & $\begin{array}{l}\text { Beneficiary } \\
\text { Per Center }\end{array}$ & $\begin{array}{l}\text { Percent of } \\
\text { Children } \\
\text { Benefited }\end{array}$ & $\begin{array}{c}\text { Percent of } \\
\text { Children } \\
\text { benefited } \\
\text { (6 M to } 3 \text { Yrs.) }\end{array}$ & $\begin{array}{c}\text { Percent of } \\
\text { Children } \\
\text { Benefited } \\
\text { (3 yrs. to } 6 \text { yrs.) }\end{array}$ & $\begin{array}{c}\text { Pregnant } \\
\text { Women } \\
\text { Benefited }\end{array}$ & $\begin{array}{c}\text { Women's } \\
\text { Literacy Rate }\end{array}$ \\
\hline Bankura & 5402 & 93.0 & 82 & 53.0 & 69.7 & 99.9 & 65.2 \\
\hline Birbhum & 4794 & 49.8 & 87.8 & 48.4 & 49.7 & 98.7 & 62.1 \\
\hline Burdwan & 9278 & 42.4 & 61 & 30.3 & 47.9 & 96.2 & 66.6 \\
\hline Kolkata & 1516 & 50.7 & 93.1 & 48.7 & 48.8 & 98.3 & 80.7 \\
\hline Kochbehar & 3973 & 63.6 & 89 & 50.3 & 48.2 & 99.1 & 66.8 \\
\hline Darjeeling & 3860 & 78.3 & 90.3 & 53.4 & 49.9 & 98.9 & 78 \\
\hline Hooghly & 6493 & 24.0 & 78.9 & 50.1 & 51.3 & 99.3 & 76.3 \\
\hline Howrah & 4132 & 82.1 & 88.4 & 51.2 & 57.4 & 82.5 & 78.4 \\
\hline Jalpaiguri & 6973 & 64.6 & 76.3 & 48.8 & 47.0 & 92.4 & 64.2 \\
\hline Malda & 5573 & 101.5 & 81.8 & 49.6 & 70.4 & 71.8 & 64.2 \\
\hline Purba Midnapore & 5951 & 78.4 & 81.5 & 55.6 & 51.2 & 91.5 & 76.1 \\
\hline Murshidabad & 8580 & 45.8 & 75.1 & 42.6 & 46.6 & 99.2 & 66.1 \\
\hline Nadia & 6345 & 59.6 & 80.6 & 48.8 & 51.6 & 98.0 & 73.7 \\
\hline Purulia & 4828 & 67.5 & 87.6 & 51.8 & 50.4 & 92.5 & 48.1 \\
\hline North 24 Parganas. & 10047 & 68.4 & 60.5 & 29.6 & 44.4 & 96.4 & 82.9 \\
\hline Uttar. Dinajpur & 3737 & 85.8 & 90.9 & 52.1 & 50.3 & 87.6 & 51.1 \\
\hline South 24 Parganas. & 10640 & 33.7 & 39.1 & 9.8 & 8.8 & 100.0 & 74.6 \\
\hline Dakshin. Dinajpur & 3231 & 308.9 & 92.1 & 91.2 & 90.2 & 86.0 & 67.3 \\
\hline Paschim Medinipur & 8720 & 69.3 & 74.1 & 49.7 & 51.2 & 91.5 & 70.7 \\
\hline
\end{tabular}

Source: Health on the March2015-16 Report

Fourthly, the percentage share of benefited children from ICDS under the age group 6 month to 3 years varied from 9.8 per cent in Hooghly to 55.6 percent in Purba Midnapore i.e. the share was highest in Purba Medinipur followed by Birbhum (53.4), Murshidabad (53 per cent), Malda (52. 1 percent). Whereas very weak performance was observed for the 6 months to 3-year children benefited from AWCs in Hooghly (9.8percent) districts followed by Nadia (29.6 percent), Burdwan (30.3 percent) and Kolkata (42.6).

Fifthly, in 2015-16 the percentage of children aging 3 to 6 years who were benefitted from AWCs gave a very contrasting result. On the one hand the highest percentage was observed in Hooghly (90.2 percent) followed by Nadia (70.4 percent), Burdwan (69.7 percent) and on the hand the lowest percentage was observed in Purba Medinipur (44.4 percent) followed by Birbhum (46.6 percent), Mursidabad (47 percent), and Malda (47.9 percent).

\section{Woman Literacy Rate across Districts in West Bengal}

In fig. 1 we have shown the percentage of woman literacy rate across district of West Bengal. The percentage of Woman literacy rate varied from 82.9 per cent in North 24 Pargana to 48.1 per cent in Purulia.

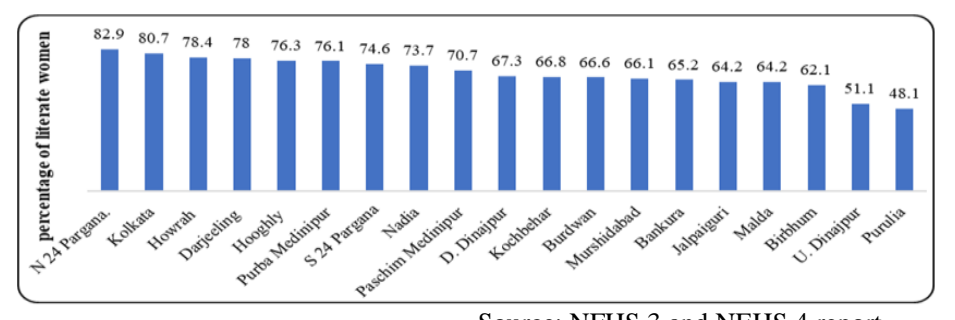

Source: NFHS 3 and NEHS 4 report

Fig. 1 Woman literacy rate across districts in West Bengal in 2015-16

On the basis of a number of socio-economic indicators, the districts of West Bengal are sub-divided into two groups namely relatively developed districts and relatively less developed districts (Indian Rural Development Report 2013-14). Out of total 19 districts of West Bengal eight are relatively developed and the rest are relatively less developed. The less developed districts are Jalpaiguri, Paschim Medinipur, Mursidabad, Kochbehar, Dakshin Dinajpur, Bardwan, Bankura, Malda, Uttar Dinajpur, Purulia and developed districts includes Kolkata, North 24 Parganas, Hugli, Darjeeling, Howrah, Birbhum, Purba Medinipur, Nadia, and South 24 Parganas. 
TABle II T- Test Result Of Different Situation Of Child Health OF BACKWARD AND DEVELOPED DISTRICTS OF WEST BENGAL

\begin{tabular}{|l|c|c|c|c|}
\hline & Backward & Developed & $\begin{array}{c}\text { Mean } \\
\text { Difference }\end{array}$ & t-Value \\
\hline $\begin{array}{l}\text { Women } \\
\text { Literacy }\end{array}$ & 63.03 & 75.86 & -12.83 & $-4.16^{* * *}$ \\
\hline $\begin{array}{l}\text { Beneficiary } \\
\text { Child From } \\
\text { ICDS }\end{array}$ & 74.27 & 84.16 & -9.88 & $-1.62^{* * *}$ \\
\hline $\begin{array}{l}\text { Project } \\
\text { Operational } \\
\text { of ICDS }\end{array}$ & 29 & 31.66 & -2.7 & -0.4 \\
\hline
\end{tabular}

Sources: Author's Calculation, ${ }^{* * *}$ denotes significant at 1 per cent level

Women literacy and children benefitted from ICDS of the backward region is significantly lower than that of the developed region in West Bengal. But there is no significant difference of Operation of ICDS between developed and backward region (Table II).

\section{B. Nutritional Status of Child Health across the Districts of West Bengal, 2005-06 \& 2015-16}

Children's nutritional status in West Bengal has improved since NFHS-3 in case of some indicators. The percentage of stunted children decreased from 45 percent to 33 percent whereas the percentage of children who are underweight decreased from 39 percent to 32 percent over the decade between NFHS-3 and NFHS-4. However, in the same period, wasting increased slightly (from 17 percent to 20 percent). Despite the reduction in stunting and underweight, child malnutrition is still a major problem in West Bengal. There are mere differences in the level of undernutrition on the basis of sex of the child. However, differences are more pronounced in case of other indicators. Undernutrition generally decreases with increasing mother's schooling, their better nutritional status and larger size of the child at birth. The level of stunting and underweight is relatively high for children of higher birth orders.

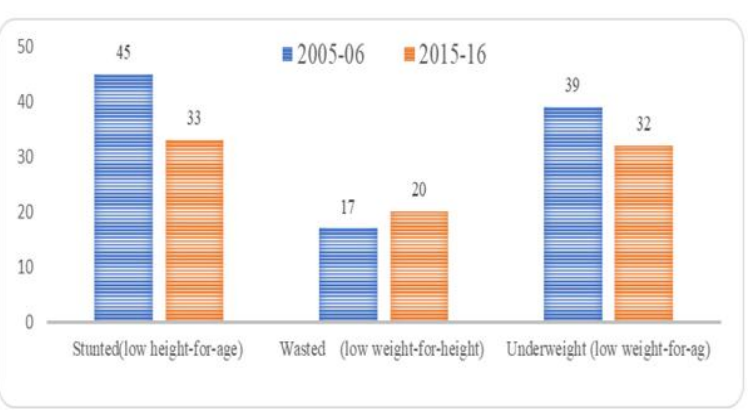

Source: Report of NFHS 3 and NFHS 4

Fig. 2 Percentage of stunted, wasted and underweight children in West Bengal, 2005-06 and 2015-16

Table Ii Status Of Underweight, Stunted And Wasted Children Across Districts Of West Bengal In 2015-16

\begin{tabular}{|l|c|c|c|}
\hline Name of the Districts & Percent of stunted children & Percent of wasted children & Percent of underweight children \\
\hline Bankura & 34 & 27 & 39.8 \\
\hline Birbhum & 40.5 & 29.5 & 43.1 \\
\hline Burdwan & 32.5 & 25.8 & 33.7 \\
\hline Kolkata & 24.2 & 17.4 & 19.6 \\
\hline Kochbehar & 32.9 & 20.1 & 29.3 \\
\hline Darjeeling & 29.1 & 11.3 & 3.7 \\
\hline Hooghly & 30.1 & 18.5 & 28.7 \\
\hline Howrah & 34.6 & 14.6 & 28.4 \\
\hline Jalpaiguri & 31.2 & 17.7 & 24.6 \\
\hline Malda & 37.8 & 22.8 & 37.2 \\
\hline Purba Medinipur & 29.9 & 24.5 & 32.8 \\
\hline Murshidabad & 41.9 & 17.5 & 34.6 \\
\hline Nadia & 23.3 & 10.7 & 19.3 \\
\hline Purulia & 45.5 & 34.6 & 58.2 \\
\hline N 24 Pgs. & 23.8 & 13.6 & 18.3 \\
\hline U. Dinajpur & 40.4 & 14 & 34.7 \\
\hline S 24 Pgs. & 27.3 & 20.1 & 27.8 \\
\hline D. Dinajpur & 32.9 & 17.1 & 28.1 \\
\hline Paschim Medinipur & 29.4 & 28 & 40.3 \\
\hline
\end{tabular}

There is remarkable variation among the districts in respect of children who are Stunted (Table III). Purulia ranked first with 45.5 percent in 2015-16 followed by Murshidabad (41.9 percent) Birbhum (40.5 percent), Uttar Dinajpur (40.4 percent) whereas its percentage share is relatively low in
Nadia (23.3 percent) North 24 Pargana (23.8 percent) and Kolkata (24.2 percent).

There is remarkable variation among the districts in respect of the percentage of wasted children. Purulia ranked first 
with 34.6 percent in 2015-16 followed by Birbhum (29.5 percent), Paschim Medinipur (28 percent) and Bankura (27percent). In Nadia districts the percentage share of wasted child was relatively low this was 10.7 percent. Moreover, districts like Darjeeling (11.3percent), North 24 Pargana (13.6percent), and Uttar Dinajpur (14percent) followed the same path [Table III]. There is remarkable variation among the districts in respect of underweight children. Birbhum had the worst condition which was 43.1 percent in 2015-16 followed by Paschim Medinipur (40.3percent), Bankura (39.8percent), Malda (37.2percent), Uttar Dinajpur (34. 7percent). In Darjeeling districts, the percentage share of under waited children were relatively low that is 3.7 percent whereas North 24 Pargana (18.3 percent), Nadia (19.3 percent), and Kolkata (19.6 percent) followed it [Table III].

TAble Iv T- Test Result Of Different Situation Of Child Health OF BACKWARD AND DEVELOPED DISTRICTS OF WEST BENGAL

\begin{tabular}{|l|c|c|c|c|}
\hline & Backward & Developed & $\begin{array}{c}\text { Mean } \\
\text { Differenc }\end{array}$ & t-Value \\
\hline Wasted & 35.85 & 29.2 & 6.65 & $2.66^{* * *}$ \\
\hline Stunted & 22.46 & 17.8 & 4.66 & 1.61 \\
\hline $\begin{array}{l}\text { Under } \\
\text { Weight }\end{array}$ & 36.05 & 24.6 & 11.4 & $2.45^{* * *}$ \\
\hline
\end{tabular}

Sources: Author's Calculation, ${ }^{* * *}$ denotes significant at 1 percent level

Stunted and Wasted child of backward region is significantly higher than in the developed regions of West Bengal. But there is no significant difference of Stunted child between developed and backward region (Table IV).

\section{Percentage of Children Received Various Benefits from the Anganwadi Centre Services in West Bengal}

The ICDS programme provides nutrition and health services for children under the age of six years and pregnant or lacting women, as well as pre-school activities for children age 3-5 years. These services are provided through community-based Anganwadi centers. Seventy-four percent of children under 6 years received services of some kind from the Anganwadi centers. The most common services that age-eligible children receive are supplementary food, 73 per cent in 2015-16 which was only 40 percent in 200506, growth monitoring 39 percent in 2005-06 whereas 70 percent in 2015-16, health check-ups in 2005-06 was 25percent which increased to 65 percent in 2015-16 and immunizations increased from 12 percent in 2005-06 to 42 percent in 2015-16. Two-thirds of children received early childhood care or pre-school care in 2015-16 (67 percent of children age 3-6 years).

Less than three-fourths of the mothers of children who were weighed at an Anganwadi center (73percent) received service from an Anganwadi worker or an ANM. Among children under 6 years, almost three-fourths of their mothers i.e. 42 percent in 2005-06 and 74 percent in 2015-16 received service from an Anganwadi center during pregnancy, and 70 percent of mothers received service during lactation.

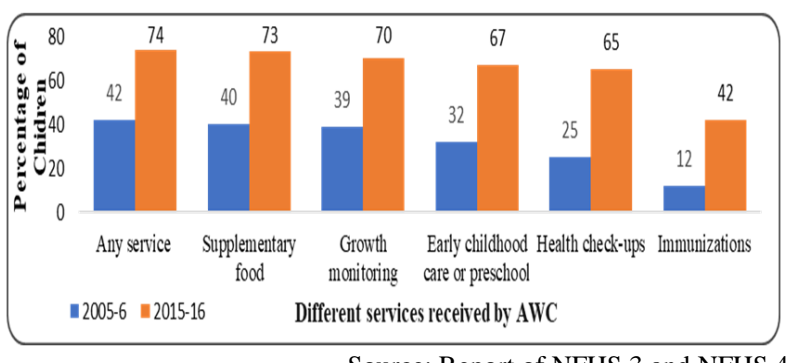

Source: Report of NFHS 3 and NFHS 4

Fig. 3 Percentage Distribution of children receiving services from ICDS in West Bengal, 2005-06 \& 2015-16

D. Health Service Received by the Mother in the Form of Antenatal Care (ANC) in West Bengal

The present section analyses the Health service of women during pregnancy and a live birth in the five years preceding the survey from different antenatal care (ANC). Antenatal care is the routine health control of reputed healthy pregnant woman without symptom (screening) in order to diagnose on in case of complicating obstetric condition without symptom, and to provide information about delivery. There are some important features of ANC which are as follows. (1) Maintenance of health of mother during pregnancy, (2) Identification of high-risk case appropriate management, (3) Prevent development of complication, (4) Derrises maternal and infant mortality morbidity. (5) Removing the stress and worries of the mother regarding the delivery process. (6) Teach the mother about child care, nutrition, sanitation and hygiene. (7) Advice about family planning. (8) Care of the under-fives accompanying mother. In West Bengal there has been a direct increment in the percentage of women form 56.5 percent in 2005-06 to 78.9 percent in 2015-16 who received ANC from a doctor whereas the per cent of women who receive ANC form other skilled providers like ANM/Nurse/midwife/LHV or other health personal like an Anganwadi / ICDS worker had deteriorated over the last 10 years (Fig. 4).

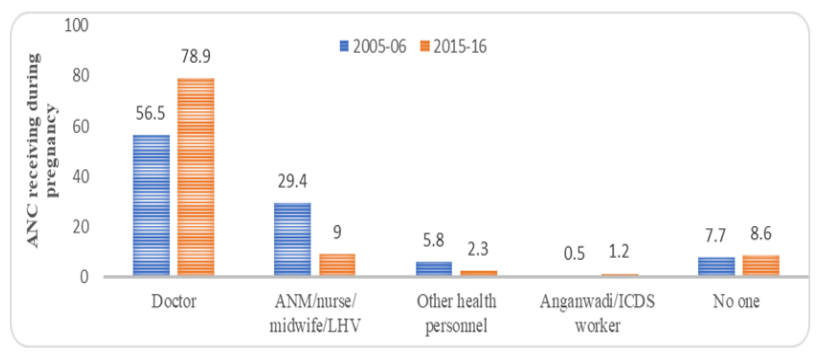

Source: Report of NFHS 3 and NFHS 4

Fig. 4 Health services received by mothers who had a live birth in the last five years in West Bengal, 2005-06 and 2015-16

\section{ANALYSIS OF THE STUDY}

1. Analysis of the Status of Child Health in Relation to the Performance of ICDS across Districts in West Bengal

A. Model-1: Analysis of Underweight Children: Here we regress percentage of Underweight Children on number of 
AWCs, no of child benefited per AWC, Women Literacy Rate, Number of ICDS Working Projects, and GDI of per CDPO \& AWC per Supervisor for the year 2015-16. Regression Model is specified as follows $Y_{i}=\alpha_{0}+\alpha_{1} X 1_{i}+\alpha_{2} X 2_{i}+\alpha_{3} X 3_{i}+\alpha_{4} X 4_{i}+\varepsilon_{i}---(1)$ Where,
$\mathrm{Y}_{\mathrm{i}}=$ percentage of Underweight Children

$\alpha_{0}=$ constant

'I'=1 to 19 (19 Districts of West Bengal)

$\varepsilon_{\mathrm{i}=}$ Random error term

TABLE V ESTIMATEd ReSUlts OF THE REgRession EQUATION FoR UNDERWEIGHT CHILDREN

\begin{tabular}{|c|c|c|c|c|}
\hline \multicolumn{5}{|c|}{ 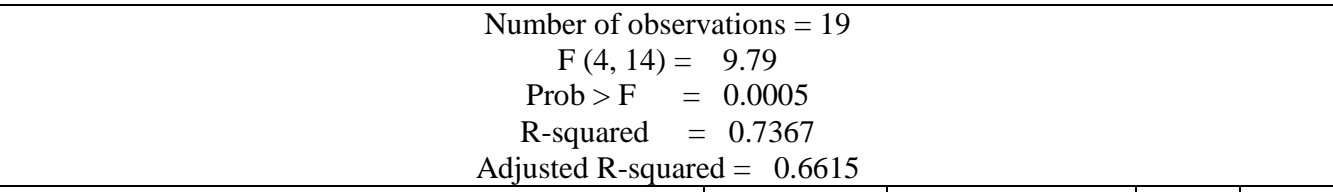 } \\
\hline & Coefficient & Standard Error & t stat & $\mathbf{P}>\mathbf{t}$ \\
\hline $\mathrm{X} 1=$ Percentage of child benefited from AWC's & -0.73 & 0.26 & -2.8 & 0.014 \\
\hline $\mathrm{X} 2=$ women literacy rate & -0.96 & 0.22 & -4.41 & 0.001 \\
\hline X3 = No of ICDS Working Projects & -0.26 & 0.13 & -1.93 & 0.074 \\
\hline X4 = GDI value of per CDPO \& AWC per Supervisor & 0.23 & 7.06 & 0.03 & 0.974 \\
\hline Constant & 147.50 & 22.87 & 6.45 & 0.000 \\
\hline
\end{tabular}

Here the model is good fitted at 1 percent level with F-value as 9.79 and the adjusted R-square is 0.66 (Table V). There is a significant relation between the dependent and three independent variables. The percentage share of underweight children is negatively and significantly related to percentage of benefited children from ICDS. This means that if the benefitted child from ICDS increases then it will result in decrease of underweight child. Women literacy is negatively related to child's underweight at 1 percent level. The number of ICDS working project is negatively related to underweight child at 10 percent level. The number of ICDS working project reduces the percentage of underweight children.
B. Model-2: Analysis Wasted Children: Here we regress percentage of Wasted Children on number of children benefited per AWC, Women Literacy Rate, GDI of per CDPO \& AWC per Supervisor and Number of AWCs providing SNP more than 21 days during a month for the year 2015-16. Regression Model is specified as follows

$Y_{i}=\alpha_{0}+\alpha_{1} X 1_{i}+\alpha_{2} X 2_{i}+\alpha_{3} X 3_{i}+\alpha_{4} X 4_{i}+\varepsilon_{i}---(2)$

Where,

$\mathrm{Y}_{\mathrm{i}}=$ percentage of wasted Children

$\alpha_{0}=$ constant

'I'=1 to 19 (19 Districts of West Bengal)

$\varepsilon_{\mathrm{i}=}$ Random error term

Table Vi Estimated Results Of The RegRession Equation For Wasted ChILDREN

\begin{tabular}{|c|c|c|c|c|}
\hline \multicolumn{5}{|c|}{$\begin{array}{c}\text { Number of observations }=19 \\
F(4,14)=4.79 \\
\text { Prob }>F=0.0121 \\
\text { R-squared }=0.5778 \\
\text { Adjusted R-squared }=0.4572\end{array}$} \\
\hline & Coefficient & Standard Error & t stat & $\mathbf{P}>\mathbf{t}$ \\
\hline $\mathrm{X} 1=$ Percentage of child benefited from AWC's & -0.42182 & 0.192313 & -2.19 & 0.046 \\
\hline $\mathrm{X} 2=$ women literacy rate & -0.49785 & 0.154892 & -3.21 & 0.006 \\
\hline $\begin{array}{l}\text { X3 = No of AWCs providing SNP more than } \\
21 \text { days during a month }\end{array}$ & -0.000998 & 0.000509 & 1.96 & 0.007 \\
\hline X4 = GDI value of per CDPO \& AWC per Supervisor & -7.57271 & 5.17227 & -1.46 & 0.165 \\
\hline Constant & 87.24052 & 16.64534 & 5.24 & 0.000 \\
\hline
\end{tabular}

Here the model is good fitted at 1 percent level with F-value as 4.79 and the adjusted R-square is 0.45 (Table VI). There is a significant relation between dependent and three independent variables. The percentage share of wasted children is negatively and significantly related to the percentage of benefited children from ICDS. This means that if the child benefited from ICDS increases then it will result in decrease in wasted child. Women literacy is negatively related to child who is wasted at 1 percent level. The number of AWCs providing SNP more than 21 days is negatively and significantly related to wasted child. 
C. Model-3: Stunted Children: Here we regress percentage of Stunted Children on number of children benefited per AWC, Women Literacy Rate, GDI of per CDPO \& AWC per Supervisor and No of ICDS Working Projects for the year 2015-16. Regression Model is specified as follows $Y_{i}=\alpha_{0}+\alpha_{1} X 1_{i}+\alpha_{2} X 2_{i}+\alpha_{3} X 3_{i}+\alpha_{4} X 4_{i}+\varepsilon_{i}----(3)$
Where,

$\mathrm{Y}_{\mathrm{i}}=$ percentage of Stunted Children

$\alpha_{0}=$ constant

'I' $=1$ to 19 (19 Districts of West Bengal)

$\varepsilon_{\mathrm{i}}=$ Random error term

TABLE ViI Estimated Results Of THE Regression EQuATION For STUNTEd CHILDREN

\begin{tabular}{|c|c|c|c|c|}
\hline \multicolumn{5}{|c|}{$\begin{array}{c}\text { Number of Observation }= \\
F(4,14)=10.22 \\
\text { Prob }>F=0.0004 \\
\text { R-squared }=0.7450 \\
\text { Adjusted R-squared }=0.6721\end{array}$} \\
\hline & Coefficient & Std. Error & t stat & $\mathbf{P}>\mathbf{t}$ \\
\hline $\mathrm{X} 1=$ Percentage of child benefited from AWC's & -0.25173 & 0.141412 & -1.78 & 0.097 \\
\hline $\mathrm{X} 2=$ women literacy rate & -0.47645 & 0.117329 & -4.06 & 0.001 \\
\hline $\mathrm{X} 3=$ No of ICDS Working Projects & -0.00691 & 0.071458 & -0.1 & 0.011 \\
\hline $\mathrm{X} 4=$ GDI value of per CDPO \& AWC per Supervisor & 3.99465 & 3.802516 & 1.05 & 0.924 \\
\hline Constant & 83.3174 & 12.31377 & 6.77 & 0 \\
\hline
\end{tabular}

Here the model is good fitted at 1 percent level with F-value as 9.79 and the adjusted R-square is 0.66 (Table VII). There is a significant relation between dependent and two independent variables. The percentage share of Stunted children is negatively and significantly related to percentage of benefited children from ICDS. This means that if the benefited child from ICDS increases then the percentage of Stunted child will decrease. Women literacy is negatively related to Stunted child at 1 per cent level.

\section{CONCLUSION}

Children's nutritional status in West Bengal has improved from 2005-06 to 2015-16 in case of some indicators. Percentage of Stunting children decreased from 45 percent to 33 percent, whereas the percentage of underweight children decreased from 39 percent to 32 percent but at the same period, the percentage of wasting children increased slightly (from 17 percent to 20 percent). In 2015-16, among the districts in respect of underweight children, Birbhum had the worst condition followed by Paschim Medinipur, Bankura, Malda and Uttar Dinajpur. Whereas in respect of Stunted children top five districts were Purulia, Murshidabad, Birbhum and Uttar Dinajpur.

The percentage of wasting children was highest in Purulia followed by Birbhum, Paschim Medinipur and Bankura. The coverage of various health and nutrition programmes for the child has significantly increases from before. 73 percent of children received supplementary food, 65 percent of the children received health check-ups, while immunizations increased to 42 percent in 2015-16. Twothirds of children received early childhood care and 70 percent of the mothers received any service during lactation. In West Bengal, the percentage of women who received ANC from a doctor have increased from 56.5 percent in 2005-06 to 78.9 percent in 2015-16 and it was highest for socially disadvantage classes i.e. OBCs and SCs. Coverage and Utilization of ICDS services to the child according to their Sex in West Bengal have been also discussed. Here male child is more benefitted than female child. In the rural sector children received more facilities from ICDS centers in terms of all facilities, supplementary food and immunization etc.

From the regression estimation it is observed that the percentage of wasted, stunted and underweight children has significantly decreased overtime. The entire three models are statistically significant. Percentage of child benefited from AWC's, women literacy rate and number of ICDS Working Projects were negatively and significantly related to the percentage of underweight children implying that if the percentage of the children benefitted from these indicators increases then the percentage of underweight children will decrease. The percentage of child benefited from AWC's, women literacy rate, number of AWCs providing SNP more than 21 days during a month are negatively and significantly affecting the percent of wasted children.

Thus, if the percentage of the children benefitted from these indicators increases then it will result in the decline in the percentage of wasted child. Percentage of stunted children is negatively and significantly related to the percentage of child benefited from AWC's, women literacy rate and GDI value of per CDPO \& AWC per Supervisor. Thus, the percentage of stunted children will decline with the increase in the percentage of children benefitted from these indicators. If the districts have a higher percentage of literate women and AWC's then we can say that the percentage of underweight, stunted and wasting children will decreases. 


\section{REFERENCES}

[1] Bashir Aadil et al., (2014). Evaluation Study of Integrated Child Development Scheme (ICDS) in District Bandipora of Jammu and Kashmir, India. International Research Journal of Social Sciences, 3(2), 34-36.

[2] Chowdhury, S. \& Mali, S. S. (2016). Evaluation of ICDS projects and services in West Bengal, India. Acme Intellects International Journal of Research in Management, Social Sciences \& Technology. 13(13).

[3] Chudasama, R.K., Kadri, A.M., Verma, P.B., Patel, U.V., Joshi, N., Zalavadiya, D., \& Bhola, C. (2014). Evaluation of Integrated Child Development Services Program in Gujarat, India. Indian Pediatrics, 51, 707-711. Retrieved from https://doi.org/10.1007/s13312-0140486-9
[4] Ministry of Women and Child Development: Government of India (n.d.) Integrated Child Services (ICDS) Scheme. Retrieved from https://icds-wcd.nic.in/icds.aspx

[5] Mohanty, S. R. (2017). Home Science Extension Education and Rural Development. Hamburg: Anchor Academic Publishing.

[6] Mukherjee, S., \& Rome, P. (2015). Integrated Child Development Scheme - Case Studies from West Bengal. International Journal of Science and Research (IJSR), 4(6). Retrieved from ijsr.net.

[7] Report of the National Institute of Public Co-operation and Child Development (NIPCCD), New Delhi: The National Evaluation of Integrated Child Development Services, 1992.

[8] Tandon, B. N. (1989). Integrated child development scheme consultants: immunization coverage in India for areas served by the ICDS. WHO Bulletin 1992, 70(4):461- 465. 